\title{
The Effects of the Trade and Investment Partnership Agreement on the European Union and Turkey
}

\author{
Asst. Prof. Dr. Pınar Bal (Beykent University, Turkey)
}

\begin{abstract}
The goal of this paper is to analyze the possible effects of the Transatlantic Trade and Investment Partnership (TTIP) Agreement aimed to be signed between the European Union and the United States by the end of 2015. The TTIP is expected to have important social, economic and political benefits for the European Union and the United States. In this respect, following a short description of the TTIP, the possible effects of this agreement on the European Union, the United States as well as on world trade will be described. The effects of such an agreement on Turkey will also be examined both with respect to Turkey's already existing relations with the European Union and the United States. In parallel with these, the advantages and disadvantages of the existing Customs Union Agreement between Turkey and the European Union will be evaluated with respect to the TTIP. Based on this analysis, some policy alternatives for Turkey will be proposed that might help Turkey to overcome the current disadvantages that will result from the TTIP and that might strengthen its trade relations with both the European Union and the United States by transforming those disadvantages into advantages.
\end{abstract}

\section{Introduction}

Starting with the $16^{\text {th }}$ century, trade has been perceived to be one of the most important factors for countries to increase their economic welfare and political power. In this respect, it has always been very important for countries to find new markets for their firms.

As the most powerful victor of the Second World War, the United States has also been highly motivated to establish a new world system that would be able to serve the American economic and political interests. Free trade has always been an important factor for the United States in reaching its goals in parallel with its national interests. Trade has been perceived by the United States to be a tool for creating a peaceful world order dominated by the United States. Thus; trade had a critical importance for the United States in creating wealth and power (Gilpin, 1987).

After the Second World War, the United Stated has established a global system based on free trade. With the General Agreement on Tariffs and Trade (GATT) established in 1947, 23 countries led by the United States have agreed to reduce their tariffs and quotas in an effort to make trade easier with each other. With the aim of creating a market capable of demanding the high technology products produced by the United States, the World Bank has been established in the same year with the aim of supporting infrastructure projects such as roads, highways, dams and waterways through providing long term credits. Taking into consideration that the trading nations might have difficulties in making payments for the goods that they had bought or default on their credit payments that might have put the whole system under stress, International Monetary Fund (IMF) has been established to provide short term credits. Besides, through the Bretton Woods system established in 1944, the United States has had the chance of dominating the world markets in financial terms, too. The dollar of the United States had become the reserve currency of the new economic system (Gilpin, 1987).

The United States was the dominant power of the early post-Second World War era and it was highly interested in the creation of a free trade system to provide its firms with new markets willing to buy their products with comparative advantages vis a vis the firms of other countries that had mostly been destructed by the war. However; many factors during the 1970s led to a change in the perspective of the United States. The European economies recovered quickly and the European firms started to challenge the leadership position of the American firms in world trade. In Asia, Japan and some South-East Asian countries also started to develop fast with increasing exports to the world. The low labor costs in these countries provided them with a competitive advantage in the world markets vis a vis the Western countries. As a result of these developments, the United States started to lose its dominant position and comparative advantage in world markets.

Hence, as countries other than the Unites States overcame the weaknesses in their economies after the Second World War, competition increased and world trade started to shift from the United States to the east. To be able to sell their products, countries had to look for new ways of creating comparative advantages in the world markets. In this era, new protectionism and regionalization had been the two methods utilized to deal with the new realities of the world (Gilpin, 1987). The United States had lost its previous dominance in world trade. World trading structure was changing and countries were looking for new ways of ensuring the continuation of their comparative advantages as well as their dominant positions.

New protectionism, as being one of the ways of reacting to the new realities of the changing world trading structure, involved the establishment of non-tariff barriers to restrict trade in an era where actually free trade was 
being supported. The United States, Europe and other countries of the world started to use these non-tariff barriers in an effort to protect their firms and their market shares from increasing trade competition in the world.

Regionalization has been a second way of responding to the new challenges in the world trading system. Under regionalization, integration has been found to be advantageous by some countries to create a comparative advantage towards the outsiders. The European Union (EU) in Europe, the North American Free Trade Area (NAFTA) in North America, Mercosur in South America, Asian Free Trade Area (AFTA) or Association of South-East Asian Nations (ASEAN) were all initiatives of this understanding. After the 1990s, it was expected that trade would strongly grow among the members of these blocs, but also between these blocs (Schott, 2009).

In our contemporary world, as a result of globalization, trade competition has increased more than ever. The emerging economies of the world; BRICS (Brazil, Russia, India, China and South Africa) and MINT (Mexico, Indonesia, Nigeria and Turkey) countries together with a couple of other South American and Asian countries have been increasingly challenging American and European firms at the global arena and even capturing their long held markets. Weakened by the latest financial crisis and faced with increasing competition from the rest of the world, the American and European companies are looking for ways of creating new comparative advantages in the world economy in an effort to continue with their dominant position in the world markets. The Transatlantic Trade and Investment Partnership started to be negotiated between the United States and European Union can be seen as an extension of this search for newer comparative advantages that might help them to keep their dominant position in world markets vis a vis the emerging economies of the new century.

\section{A Short Description of the Transatlantic Trade and Investment Partnership (TTIP)}

Between the United States and Europe, trade and investment have always been an important factor in bilateral relations. Therefore, the idea of a transatlantic trade and investment agreement is nothing new. Serious proposals for a comprehensive trade agreement have started to come both from the Americans as well as the Europeans as early as mid-1990s. Although a Framework for Advancing Transatlantic Economic Integration has been signed in 2007, no formal agreement has been concluded yet (Felbermayr and Larch, 2013).

In 2013, the process has been revitalized. In February 13, 2013, a joint statement has been given by the President of the United States Barrack Hussein Obama, European Council President Herman Van Rompuy and European Commission President Jose Manuel Barroso, announcing the launch of negotiations for a Transatlantic Trade and Investment Partnership between the European Union and the United States (Council on Foreign Relations Website, 06.01.2014). These negotiations that have officially started on June 14, 2013 are aimed to be concluded by 2014 (American Chamber of Commerce in France Website, 2013).

The recently launched negotiations seem to have a high chance of success due to a couple of reasons. First of all; both regions perceive the TTIP as a way of overcoming the recent financial crisis that have weakened their economies. Besides, the TTIP is being planned to serve both parties to regain their comparative advantages that they have been losing to the emerging economies. Finally, TTIP is being perceived by both parties as a new forum to establish the new trade rules and regulations of the world in the new century. The existing trade rules in the world had been established by the GATT system, which had become the World Trade Organization (WTO) in 1995, through a couple of multilateral rounds of trade negotiations. The latest round of trade negotiations under the WTO; the Doha Round has started in 2001 with the aim of providing solutions to the problems of the new era. However; for the last couple of years, it has not been possible to conclude this Round with a successful outcome. Presently, doubts are increasing about the capacity of the Doha Round of trade negotiations to be concluded with an effective outcome. In this respect, the TTIP is being perceived by both parties to serve as a place for the establishment of the new rules and regulations of the present global trade regime (Felbermayr \& Larch, 2013).

\subsection{The aim of the Transatlantic Trade and Investment Partnership Agreement}

The TTIP aims to bring the two most important economies of the world together by establishing the largest free trade and investment area in the world. The United States together with the EU produces half of the World Gross Product and $41 \%$ of global purchasing power is located in this region (Hamilton \& Quinlan, 2013). Under the TTIP, these two economically gigantic actors will meet under one free market.

The level of existing tariff barriers between the EU and the United States is already very low. Although further tariff reductions and eliminations are still aimed under the TTIP, the major aim is to reduce or eliminate the nontariff barriers (NTBs) (Francois, 2013). The NTBs include measures to protect consumer or worker health, the environment as well as the domestic producers with a mix of standards and regulations. Naturally, NTBs increase the cost and decrease competitiveness of firms. These NTBs, basically the different standards, have actually become the major obstacle to trade between the EU and the United States. Therefore, with the TTIP, the EU and the United States are aiming to harmonize each other's NTBs in an effort to eliminate the increased fixed costs for their firms. When standards are harmonized, exports would become easier and costs would be reduced for both parties. With the TTIP, both parties are aiming to improve the investment environment, too. In understanding the TTIP, trade is not enough, investment is very important, too. While the United States and EU 
have accounted for $25 \%$ of global exports and $31 \%$ of global imports in 2011, together they have accounted for $57 \%$ of inward foreign direct investment and $71 \%$ of outward foreign direct investment (Hamilton \& Quinlan, 2013).

\begin{tabular}{|lccccc|}
\hline & GDP & $\begin{array}{c}\text { GDP as \% of } \\
\text { World GDP }\end{array}$ & $\begin{array}{c}\text { Exports, } \\
\text { Goods }\end{array}$ & $\begin{array}{c}\text { Imports, } \\
\text { Goods }\end{array}$ & $\begin{array}{c}\text { Total Trade as } \\
\text { \% of World } \\
\text { Trade }\end{array}$ \\
\hline TPP* & 11,874 & 16.6 & 2,799 & 2,931 & 15.8 \\
\hline TPP* + Prospective $^{*}$ & 13,029 & 18.2 & 3,351 & 3,450 & 18.7 \\
\hline United States & 15,685 & 21.9 & 1,547 & 2,336 & 10.7 \\
\hline European Union & 16,584 & 23.1 & 2,176 & 2,311 & $12.3^{17}$ \\
\hline TPP* + Prospective + TTIP & 45,298 & 63.2 & 7,074 & 8,097 & 41.7 \\
\hline World & 71,707 & 100 & 17,875 & 18,492 & 100 \\
\hline
\end{tabular}

Note: TPP* includes Australia, Brunei, Canada, Chile, Japan, Malaysia, Mexico, New Zealand, Peru, Singapore and Vietnam; excluding U.S. Prospective indicates Korea.

Table 1: Trade Indicators for TPP and TTIP in 2012 (in billion dollars) Source: Kirişçi, K. (September 2013). Turkey and the Transatlantic Trade and Investment Partnership. Center on the United States and Europe at Brookings: Turkey Policy Paper Number 2, p. 10.

Through the TTIP, the EU and the United States are aiming to strengthen their partnership and hence the Western-dominated international liberal economic order. TTIP is being structured as a way of affirming the social, economic and political values shared by the EU and the United States (Kirişçi, 2013). Besides the TTIP, the United States is also pushing for negotiations for a Trans-Pacific Partnership (TPP) with eleven Asian countries. The TTIP and the TPP together aim to introduce a new set of principles and rules known as WTO-plus standards to govern the present international economic relations (Kirişçi, 2013). Therefore, these agreements can be seen as the revision of the post Second World War international economic system in an effort to help continue the dominance of the Western liberal economy and its values.

\subsection{The expected benefits of the Transatlantic Trade and Investment Partnership}

Trade liberalization that will occur as a result of the TTIP is expected to have positive effects both in the EU and the United States. These positive effects can be examined in micro and macro levels.

At the macro level, trade and employment is expected to increase through the abolition of the customs and reductions as well as harmonization in the NTBs. Private and public investment is expected to increase, too. As a result of these reductions and harmonizations, the fixed costs of market entry are expected to fall down. This is expected to activate and motivate the small and medium sized companies. So, as a result of the TTIP, the internationalization of the small and medium sized companies is expected to increase (Felbermayr \& Larch, 2013).

Overall, within the TTIP region, the GED Team from Bertelsmann Stiftung forecast that 2 million additional jobs can be created. However, in some countries TTIP might lead to job losses. The GED-Team forecasts that in Canada, job loss might reach 100.000 and in Turkey it might reach 95.000 (GED-Team, 2013).

The TTIP is expected to have strong welfare effects. With the TTIP, the prices of imports are expected to be lower and this will strengthen the purchasing power of incomes in both regions. Additionally, more products would be offered to the consumers which would lead to greater competition. Increased competition would lead to decreased prices that would serve the whole society (Baldwin \& Wiplosz, 2009).

Under the TTIP, the European exports to the United States are expected to increase by $28 \%$. At the macro level, the American gains are expected to reach $€ 95$ billion and the European gains are expected to reach $€ 119$ billion (Francois, 2013).

Germany is economically the most powerful European country and it exports a considerable volume of manufactured products to the United States. On the other hand, the United States have an important volume of trade in services to the EU. Therefore, this very important divergence in trade sets the necessary grounds for a trade negotiation in terms of improving the comparative advantages for both parties (Felbermayr, et.el., 2013).

At the micro level, with the TTIP, the many standards which were in fact different in the EU and the United States will be harmonized and replaced by mutually recognized standards. This will make trade easier and lower cost. A second very important benefit of the TTIP will be on intra-firm trade. Between the United States and the EU, there is a strong intra-industry and intra-firm trade (Felbermayr \& Larch, 2013). Intra-firm trade is being taxed by both parties several times, especially when the products are unfinished. With TTIP, this tax will be eliminated which will decrease costs and increase competitiveness of the companies of both parties. Another benefit concerns the opening up of public procurement projects to companies from both sides to compete which 
can benefit both the people and the companies with additional markets (American Chamber of Commerce, 2013).

Achieving the TTIP seems to be very possible due to a couple of reasons. First of all, the cost and production structures in the two blocs are very similar as well as their economic levels. They already have deep historical, cultural and political ties. These factors can make the reduction of NTBs possible which otherwise might not have been possible to achieve (Felbermayr \& Larch, 2013).

\subsection{The Effects of the Transatlantic Trade and Investment Partnership on the world}

The third countries which stay outside the TTIP are expected to be negatively affected from the TTIP and as a result lose their markets and market shares as well as their competitiveness vis a vis their counterparts in the EU and the United States.

Free trade areas (FTAs) have both trade creation and trade diversion effects (Baldwin \& Wyplosz, 2009). As a result of the TTIP, products that were previously bought from third countries would now be preferred to be bought from within the FTA due to the elimination or reduction in tariffs and NTBs. Under these circumstances, the third countries would be left at a disadvantage and lose these markets to the firms operating in the FTA (Baldwin \& Whyplosz, 2009).

At the international arena, there might be a shift away from the multilateral trade negotiations being held under the WTO to bilateral negotiations between different groups of countries in different regions. Specifically the TTIP might lead to a push to create new bilateral agreements between other blocs who are not willing to risk being left outside and lose at the global arena. For example, Brazilians have already been pushing for a EUMercosur FTA in this respect (The Economist, 24.12.2013). This might prevent the conclusion of the Doha Round of trade negotiations. With the TTIP, the EU and the United States might lose their previous appetite concerning the conclusion of a multilateral agreement under the WTO but rather prefer bilateral arrangements (Kirişçi, 2013).

Globalization has made the reorganization of international trade rules a necessity. However, due to different interests between the developed and developing countries, the Doha Round has still not been concluded since 2001. So, the TTIP has a very important role in establishing the new rules and regulations of the new trade regime that is expected to provide solutions to the trade related problems of the $21^{\text {st }}$ century. The EU and the United States perceive the TTIP as an important ground upon which to establish the new rules and show the way forward (Felbermayr \& Larch, 2013).

With the TTIP and the TPP, the United States is aiming to supplement the traditional WTO based multilateral trade talks and push for bilateral negotiations with like-minded states (Kirişçi, 2013). By this way, the Western alliance will be able to find new comparative advantages and will become more powerful to compete with the emerging economies led by China. On the other hand, the TTIP would also increase the bargaining power of the transatlantic alliance in international affairs (Kirişçi, 2013).

As a result of the TTIP, those countries that are engaging in regional arrangements might lose their willingness to make concessions at the multilateral level. On the other hand, faced with a large trade bloc, the emerging, economies outside the blocs can easily be persuaded to make concessions like Turkey, Brazil, Mexico, Canada and South Africa (Felbermayr \& Larch, 2013) (Baldwin \& Seghezza, 2010). Therefore, the main losers from the TTIP would be those countries that already have bilateral trade agreements with the EU and the United States like Turkey, Mexico, Canada or the members of the Cotonou Agreement. The TTIP is expected to "swallow" some of the market shares of these countries (Longhammer, 2008). These countries would end up facing more EU competition in the American continent and more American competition in the EU. To get rid of this risk, these countries should sign bilateral agreements with the party that they do not have an agreement with or somehow become a part of these blocs (Kirişçi, 2013).

\section{The Possible Effects of the Transatlantic Trade and Investment Partnership on Turkey}

The Transatlantic Trade and Investment Partnership affect Turkey in two spheres. In the first sphere, Turkey's political and economic relations with the United States are at stake. In the second sphere, Turkey's political and economic relations with the EU are at stake.

\subsection{The effects of the Transatlantic Trade and Investment Partnership on Turkey's relations with the United States}

Starting from the Second World War, Turkey has been a part of the international liberal order that was established by the United States. For years, Turkey and the United States have cooperated as close allies. Both countries have memberships in common institutions like NATO, the IMF, and the World Bank. Relations between the two countries have slowed down after the end of the Cold War. In 2009, President Obama has proposed the idea of a "Model Partnership" between Turkey and the United States; however, it has not been possible to operationalize this idea significantly until the present day. According to Kirişçi, if Turkey can be 
involved in the TTIP, this would give concrete life to the idea of "model partnership" and it would be the means to reconnect Turkey to the transatlantic alliance strongly (Kiriş̧̧i, 2013). This would strengthen economy and democracy in Turkey. During the visit of Turkish Prime Minister Recep Tayyip Erdoğan to the United States in May 2013, ways of involving Turkey in the TTIP has been discussed (Kiriş̧i, 2013) (National Interest, 16.05.2013).

\begin{tabular}{|c|c|c|c|c|c|c|c|c|c|c|c|c|}
\hline \multirow[b]{2}{*}{ Turkey } & \multicolumn{4}{|c|}{1992} & \multicolumn{4}{|c|}{2002} & \multicolumn{4}{|c|}{2012} \\
\hline & Export & Import & Total & $\begin{array}{l}\% \text { of } \\
\text { Total }\end{array}$ & Export & Import & Total & $\begin{array}{l}\% \text { of } \\
\text { Total }\end{array}$ & Export & Import & Total & $\begin{array}{l}\% \text { of } \\
\text { Total }\end{array}$ \\
\hline EU & 7.600 & 10.049 & 17.649 & $47 \%$ & 18.458 & 23.321 & 41.779 & $48 \%$ & 59.201 & 87.448 & 146.649 & $38 \%$ \\
\hline US & 865 & 2.600 & 3,465 & $9 \%$ & 3.356 & 3.099 & 6.455 & $7 \%$ & 5.604 & 14.130 & 19.734 & $5 \%$ \\
\hline Neighborhood & 1.866 & 2.162 & 4.028 & $11 \%$ & 3.998 & 7.08 & 11.806 & $13 \%$ & 39.398 & 53.386 & 92.784 & $24 \%$ \\
\hline Middle East & 2.516 & 3.126 & 5.642 & $15 \%$ & 3.504 & 2.432 & 5.936 & $7 \%$ & 45.665 & 22.487 & 68.152 & $18 \%$ \\
\hline Israel & 90 & 97 & 187 & $0.5 \%$ & 861 & 544 & 1.405 & $2 \%$ & 2.330 & 1.710 & 4.040 & $1 \%$ \\
\hline $\begin{array}{l}\text { Trans-Pacific } \\
\text { Partnership (TPP) }\end{array}$ & 1.245 & 4.252 & 5.497 & $15 \%$ & 4.229 & 5.748 & 9.977 & $11 \%$ & 8.812 & 23.694 & 32.506 & $8 \%$ \\
\hline South Korea & 191 & 373 & 564 & $2 \%$ & 55 & 900 & 955 & $1 \%$ & 528 & 5.660 & 6.188 & $2 \%$ \\
\hline China & 147 & 172 & 319 & $1 \%$ & 268 & 1.368 & 1.636 & $2 \%$ & 2.833 & 21.295 & 24.128 & $6 \%$ \\
\hline Sun-Saharan Africa & 146 & 233 & 379 & $1 \%$ & 430 & 381 & 811 & $1 \%$ & 3.913 & 2.613 & 6.526 & $2 \%$ \\
\hline Others & 1.943 & 2.915 & 4.858 & $13 \%$ & 5.447 & 10.600 & 16.047 & $18 \%$ & 16.613 & 39.964 & 56.577 & $15 \%$ \\
\hline Turkey TOTAL & 14.715 & 22.871 & 37.586 & $100 \%$ & 36.059 & 51.554 & 87.613 & $100 \%$ & 152.469 & 236.545 & 389.014 & $100 \%$ \\
\hline
\end{tabular}

EU-12 for 1992, EU-15 for 2002, EU-27 for 2012

Neighborhood: Bulgaria, Greece, Romania, Moldova, Russia, Ukraine, Azerbaijan, Georgia, Iran, Iraq, Syria

Middle East: Iran, Iraq, Syria, Lebanon, Jordan, GCC, Yemen, North Africa (Egypt, Libya, Algeria, Morocco, Tunisia)

TPP: Australia, Brunei, Chile, Canada, Japan, Malaysia, Mexico, New Zealand, Peru, Singapore, USA, Vietnam.

Sub-Saharan Africa: TUIK category of "Other Africa".

Note that figures for Bulgaria, Greece and Romania appear both with the EU and Neighborhood totals; figures for Iran, Iraq and Syria appear both in the Middle East as well as Neighborhood totals and figures for U.S. appear in the TPP total.

2012 data is provisional

Table 2: Trade Indicators for TPP and TTIP in 2012 (in billion dollars) Source: Kirişçi, K. (September 2013). Turkey and the Transatlantic Trade and Investment Partnership. Center on the United States and Europe at Brookings: Turkey Policy Paper Number 2, p. 12.

Table 2 shows that the American share within total Turkish foreign trade has fallen from 9\% in 1992, to 7\% in 2002 and $5 \%$ in 2012 . This decline actually shows that there is a need to revitalize trade relations between the United States and Turkey. TTIP can be seen as a historical opportunity to revitalize the relations between these two countries and to strengthen Turkey's ties and relations as well as place within the transatlantic partnership. If Turkey cannot be anchored to the TTIP, it might be possible to expect the share of the United States within Turkey's trade to fall further. This would push Turkey to establish new trade relations or strengthen other trade relations instead of the United States. Trade is a very important component of the present era to establish cooperation among the countries. Without trade, interdependence would not develop and as a result countries might lose their ground for cooperation and alliance. Hence, without the economic component, the long standing alliance between the United States and Turkey might be weakened in political aspects, too. In a region full of instabilities, this would be to the disadvantage of both parties. Whereas, with the TTIP it might be possible to strengthen relations to the advantage of both parties.

3.2 The effects of the Transatlantic Trade and Investment Partnership on Turkey's relations with the EU

Turkey's relations with the EU go back to 1963 when Ankara Agreement was signed between Turkey and the European Economic Community (EEC). In 1973, an Additional Protocol has come into effect with the aim of establishing a Customs Union in a timetable of 22 years. When all necessary preparations were finalized, the Customs Union has come into effect as of January 1, 1996. The Customs Union has been a very important catalyst in the integration of Turkey to the EU and to the Western liberal economic order. It has also been a very important supporter of Turkey's economic rise in the last couple of years. With the help of the Customs Union, Turkey has been able to align its regulations and rules in the legal and economic spheres with those of the EU and the world. Presently, Turkey ranks the $17^{\text {th }}$ largest economy in the world motivated with higher ambitions for the future.

Although Customs Union has supported Turkey's modernization and economic rise in the last couple of years, due to its nature Turkey cannot become a member of the TTIP automatically due to its Customs Union Agreement with the EU since it is not a member of the EU. According to the Customs Union Agreement between Turkey and the EU, Turkey accepts to obey the common foreign trade policy of the EU applied towards the third countries. In parallel with this, when the EU signs a new FTA agreement with a third country, Turkey accepts and opens its borders freely to this country. However, the Customs Union Agreement does not require that third party 
to open up its borders freely to Turkey. Therefore, for all the FTAs that the EU has finalized, Turkey has made individual attempts to establish a similar FTA with that country in an effort to obtain reciprocal rights of trade with that country. In the same manner, concerning the TTIP, Turkey will be required to open up its borders to the United States due to its Customs Union Agreement with the EU. However, the United States will not be required to open up its borders to Turkey reciprocally. Therefore, the TTIP being negotiated between the EU and the United States presents a disadvantage for Turkey (Longhammer, 2008), (Kirişçi, 2013) and threatens its future economic and political performance.

Table 2 shows that the EU's share within the total foreign trade of Turkey has fallen from $48 \%$ in 1992 to $47 \%$ in 2002 and to $38 \%$ in 2012. This decline can partially be explained due to the financial crisis that the EU has been struggling since 2008. On the other hand, over the years, Turkey has been able to increase its total trade volume notably with its neighbors and specifically with China. However, with the TPP countries, its trade has fallen from $15 \%$ in 1992 to $11 \%$ in 2002 and even to $8 \%$ in 2012.

Despite the decreasing percentage of trade with both the United States and the EU, the share of the United States and EU countries within total Turkish foreign trade is about $43 \%$ which is a very high volume making these markets still very important for Turkey. Therefore, Turkey should not be left outside of any deal that will be finalized between these two parties.

As mentioned before, the United States and EU are trying to restructure the international trading regime with bilateral or regional agreements. Trade is expected to concentrate within these regions where special agreements are taking place as well as between the regions. Hence, in parallel with these, there might be new deals between the TTIP and TPP in the near future. According to Table 1, TPP together with prospective members account for $18.2 \%$ of world GDP and their share in world's total trade is $18.7 \%$, higher than the EU or the United States. Therefore, TTIP serves as a very important connection for Turkey to establish ties with that part of the world where trade is rapidly shifting to. In 2012, the TTIP, TPP and the prospective new countries together have constituted $63 \%$ of the world's GNP and $42 \%$ of world trade. This makes up a huge market with common regulatory systems, rules and harmonized policies which will make it very easy and advantageous for the members to engage in trade. For the outsiders, making trade will become harder and higher cost. It is highly possible that the outsiders will lose some of their markets within these regions to the local firms of those regions.

\section{Policy Alternatives for Turkey}

When TTIP and TPP are concluded, Turkey will be located in the middle of these huge regional trade blocs. Turkey with high ambitions to become one of the most successful economies of the world in the years to come, cannot and should not stay outside such an important formations. The future trade regime is being shaped within and between these blocs. So, Turkey should also become a member of these blocs. Looking back at the post Second World War developments, Turkey is already a prominent member of the Western alliance; therefore, trying to include Turkey within these developments should not be so hard.

Practically, the Customs Union Agreement between Turkey and the EU seem to be the root of the problem in the sense that this agreement does not let Turkey to enter the US markets freely while it gives the US this right. If Turkey had been a member of the EU, such a problem would not be valid. However; if the Customs Union Agreement was not signed and put into force, it would again be very hard for Turkey to push for a way of getting itself to this TTIP deal. Since Turkey already has the Customs Union Agreement with the EU for the last couple of years, it has already harmonized its regulations, rules, laws and policies with the EU. Presently, this gives Turkey the grounds to push for making an arrangement to include Turkey in the TTIP deal as well. If the Customs Union has not been in place and if the necessary adaptation of Turkey has not yet taken place, Turkey would not even be able to argue to become a member of the TTIP.

Based on these grounds, there are two strategies for Turkey to work on. The first one concerns the United States. Turkey can ask the United States to sign a separate FTA with Turkey. So Turkey would also have access to the American markets without any disadvantages. This can be seen as a good starting point to operationalize the "Model Partnership" that was established to enhance relations with Turkey. However, under these circumstances, Turkey would not become an actual part of the TTIP. It would not be a part of the decision making structure. Therefore, it would not be in a position to manage its interests within the TTIP. This strategy can only minimize the threat that TTIP would present on Turkey.

The second strategy concerns the European Union. As mentioned before, there is already a Customs Union Agreement between Turkey and the EU. Based on Table 2, it is possible to argue that the Customs Union is not able to increase trade between Turkey and the EU. The Customs Union Agreement has been very useful in harmonizing and adapting Turkey's policies, laws and regulations to the EU. However, for the time being, it seems to have completed its mission. Presently, if the EU membership is still a goal for Turkey, the stalled relations should somehow be revitalized. Otherwise, EU membership is being perceived with despair in Turkey in the last couple of years. The prospect of EU membership is losing support both from the government and from the public day by day. Although attempts have been made in 2011 to revive relations under a Positive Agenda, 
tangible results have not been attained yet. The accession negotiations have opened in 2005. However, a few negotiation chapters have been opened and others are still waiting to be opened not to mention some of the blocked ones. After a rather long period of time, Chapter 22 on Regional Policy and Coordination of Structural Instruments has been opened on November 5, 2013, which has not been found to be satisfactory by the Turkish officials (Hürriyet Daily News, 05.11.2013). Therefore, both the EU and Turkey are aware of the weakening in their relations. The parties are looking for an appropriate ground to revive their relations. Under these circumstances, the best thing to do would be to restructure the Customs Union Agreement which is not serving the integration between the EU and Turkey anymore. Adjusting the Customs Union Agreement to the needs of the present day by guaranteeing that Turkey would also become a full member of the TTIP, might serve the interests of all the parties both economically and politically. There is no need to search for other alternatives to revive the integration process between Turkey and the EU. The Customs Union which cannot function is already there to help this revival.

If Turkey cannot take place within the TTIP, a third strategy comes into being. Then, Turkey's economic and political ties with the Western world might be expected to weaken further. Turkey would be forced to look for other regions in an effort to compensate for the loss of its long standing allies. This would be to the disadvantage of all.

\section{Conclusion}

With the new century, the world continues to change and adapt itself to the new developments. The trading regime of the post Second World War era is also adapting itself to the new developments. The superpower of the world, the United States has started to face increasing competition in world trade especially from the emerging economies of the globalization era. The multilateral trade negotiations that had been achieved under the WTO following the Second World War cannot function in the $21^{\text {st }}$ century. The Doha Round of trade negotiations launched in 2001 under the WTO has still not been concluded. Under these circumstances, countries are looking for solutions in bilateral or regional agreements. The most important initiative in this respect has been the Transatlantic Trade and Investment Partnership aimed to be established between the United States and the EU. With TTIP, EU and the United States are planning to establish a huge free trade area where regulations, rules and standards have been harmonized. By this way, the transatlantic alliance is aiming to solve the many problems that they face presently like fighting unemployment, creating new jobs, building new comparative advantages that will help the dominance of the United States and the EU in world trade as well as establishing the new trade rules and standards of the new era and imposing them on the rest of the world, in other words, restructuring the trade regime that had been established at the end of the Second World War. The TTIP is being planned to be supported by another similar attempt at the Asian continent under Trans Pacific Partnership. Those countries that cannot become a part of these huge trade blocs would be at a disadvantage at the international arena.

Turkey, as being a candidate member of the EU and a long standing ally of the United States and with high motivations to continue its economic rise should also become a part of this new arrangement. Although Turkey and the EU have the Customs Union Agreement, this agreement does not provide Turkey with advantages in the TTIP but on the contrary it creates disadvantages for Turkey. As a result of the TTIP, Turkish borders are opened to the United States but the American borders are not opened to Turkey. Although Turkish trade volume with the United States is not so high, facing increased American competition in Europe would certainly hurt Turkish exporters. Besides trade and investment capacity of the world will be concentrated in these regions. Therefore, Turkey should become a part of the TTIP. Turkey should use all its "diplomatic efforts" to restructure the Customs Union Agreement in parallel with the urgent needs of the present day that will make Turkey an active member of the TTIP.

\section{References}

- American Chamber of Commerce in France, "The Transatlantic Trade and Investment Partnership" July 2013 Report. http://www.amchamfrance.org/assets/position_papers/12376_backgrounder-amcham-france-28july-201329-2.pdf , Accessed on: 01.12.2013.

- Baldwin, R. E. and Elena Seghezza (2010), “Are Trade Blocs Building or Stumbling Blocs?” Journal of Economic Integration, 25 (2), June; 276-297.

- Baldwin, R. and C. Wyplosz (2009), "The Economics of European Integration”, UK: McGraw-Hill.

- Council on Foreign Relations Website, "Joint Statement on U.S.-EU Negotiations for a Transatlantic Trade and Investment Partnership, February, 2013”, published on February 13, 2013. http://www.cfr.org/trade/jointstatement-uzsz-eu-negotiations-transatlantic-trade-investment-partnership-february-2013/p30014 Accessed on: 06.04 .2014 .

- Felbermayr, G. J. and M. Larch (2013)," The Transatlantic Trade and Investment Partnership (TTIP): Potentials, Problems and Perspectives", Center for Economic Studies (CES), ifo Forum 2 (June). 
- $\quad$ Felbermayr, G. M. Larch, L. Flach, E. Yalçın and S. Benz (2013), "Dimensions and Effects of a Transatlantic Free Trade Agreement between the EU and US”, Report prepared by ifo Institute commissioned by German Federal Ministry of Economics and Technology, January.

- Francois, J., M. Manchin, H. Norberg, O. Pindyuk and P. Tomberger (March 2013), "Reducing Transatlantic Barriers to Trade and Investment: An Economic Assessment", The Final Project Report by Centre for Economic Policy Research, London, prepared for the European Commission under implementing Framework Contract TRADE10/A2/A16.

- GED-Team (2013), “Transatlantic Trade and Investment Partnership (TTIP): Who benefits from a free trade deal?”, Germany: Bertelsmann Stiftung, Global Economic Dynamics (GED) Project.

- Gilpin, R. (1987), “The Political Economy of International relations”, US: Princeton University Press.

- Hamilton, D and J. Quinlan (2013), “The Transatlantic Economy 2013”, Johns Hopkins University, The Paul H. Nitze School of International Studies, Center for Transatlantic Relations.

- Hürriyet Daily News, 05.11.2013, "EU opens new chapter, Turkey asks more”. http://www.hurriyetdailynews.com/eu-opens-new-chapter-turkey-wantsmore.aspx?PageID=238\&NID=57361\&NewsCatID=351 Accessed on: 02.02.2014

- Kirişçi, K. (2013), “Turkey and the Transatlantic Trade and Investment Partnership”, Center on the United States and Europe at Brookings, Turkey Project Policy Paper, Number 2.

- $\quad$ Langhammer, R. (2008), "Why a Market Place Must Not Discriminate: The Case against a US-EU Free Trade Agreement”, Kiel Institute for the World Economy, Working Paper 1407.

- National Interest (16.05.2013), "Erdoğan's Obama Agenda” by Kemal Kirişçi. http://nationalinterest.org/commentary/erdogans-obama-agenda-8475?page=1 Accessed on: 10.02.2014.

- Schott, J. (2009), “America, Europe and the New Trade Order”, Business and Politics, Vol.11, Issue 3, Article 1, pp. 1-22.

- The Economist, (14.12.2013), "EU-Mercosur Trade Talks: Strategic patience runs out". http://www.economist.com/news/americas/21591629-last-brazil-keen-trade-deal-strategic-patience-runs-out Accessed on: 10.03.2014. 